\title{
TRANSFORMING ART IMAGE INTO DESIGN IN THE EXAMPLE OF SALVADOR DALI'S ARTWORKS
}

\author{
SALVADOR DALI'NIN ESERLERİ ÖRNEĞİNDE SANAT İMGESINIIN TASARIMA \\ DÖNÜŞTÜRÜLMESI
}

\section{DOI:10.17755/esosder.60074}

Doğan ARSLAN ${ }^{1}$

\section{$\ddot{O} \mathbf{z}$}

Sanat ve Tasarım arasındaki güçlü bağların oluşmasında özellikle 20 Yüzyıl'ın ilk çeyreğinde Avant-Garde sanat akımlarının bazı sanatçıları, bizzat dönemin tasarım sürecinin içinde olması sebebiyle önemli rol oynamışlardır. Bu araştırmada gerçeküstü sanat akımının en önemli ve bilinen temsilcilerinden Salvador Dali'nin eserleri analiz edilmiştir. Elde edilen veriler 1şı̆̆ında, Dali’nin eserleri ile günümüz grafik tasarımcısı Polanyalı Francis Storowski'nin çalışmaları arasındaki benzerlikler ve farklılıklar ortaya konulmuştur. Bu araştırmada, Dali’nin eserlerinin grafik tasarımın önemli ögesi olan afiş̧ çalışmalarıyla nasıl ilişkilendirildiği Storowski'nin illüstrasyon ağırlıklı afiş örnekleriyle karşılaştırılmış.

Araştırmadaki karşılaştırmada elde edilen bulgulara göre, Dali’nin çalışmalarında görülen ölüm, korku, pesimizm ve izolasyon, Birinci Dünya Savaşı ile İspanyol iç savaşının ortaya çıkarmış olduğu sonuçlardır. Diğer taraftan Storowski'nin afiş çalışmalarında ise şiddete ve deformasyona uğramış figürlerin bir gece kabusunu andırması, sanatçının ülkesinin güçlü bir başka ülke tarafından işgal edilmesiyle ilişkilendirebilir. Her iki sanatçının çalışmalarındaki benzer anlatımları, bulundukları dönemin negatif bir sonucu olarak algılamak mümkündür.

Araştırmanın karşılaştırmalı metodolojisinden elde edilen bulguların, sanat ve tasarım alanlarında akademik araştırmalar yapan sanatçı, grafik tasarımcı, öğrenci, akademisyen ve sanatseverler için önemli tespitleri ortaya koyduğu söylenebilir.

Anahtar Kelimeler: Dali, Storowski, Sanat ve Tasarım, Gerçeküstücülük.

\begin{abstract}
Abstratc
In the First Quarter of the $20^{\text {th }}$ Century, some of the leading artists of Avant-Garde Art movements played an important role for the strong connections between art and design. These artists were also involved in graphic design during this time. Salvador Dali's works, an important and well-known Surrealist artist, will be analyzed in this study. During the analysis, Francis Starowski's works, a Polish graphic designer and illustrator, will be also compared with the works of Dali through parallel and similar connections.

According to the research, it is the result of the First World War and Spanish Civil War that shaped Dali's Works, which can been seen to be dead, fear, pessimism and isolation in his works. On the other hand, Starowski's figures in his illustrations are subjected to violence and deformation, which reminds that they are the part of a nightmare. This situation may be associated with the artist's land, which was occupied by a powerful country. It is possible to perceive that common expressions in both of the artist's works may be negative result of their period.

This research, with the comparison works of Dali and Starowski, will show that how some of the art works are transformed into graphic design area. The findings from this comparative methodology of the research will show some important results from which academic researchers, artists, designers and art lovers will get benefit.
\end{abstract}

Keywords: Dali, Storowski, Art and Design, Surrealism.

\footnotetext{
${ }^{1}$ Yrd.Doç.Dr., Sanat ve Tasarım Fakültesi Görsel İletişim Tasarımı Bölümü İnteraktif Medya Tasarımı A.B.D, arslandogan@hotmail.com
} 


\section{Introduction}

Teaching art history class in design department is necessary in most of the universities. It is important to know the general principles of art for students. The art history covers from painting to sculpture and architecture to decorative objects. The class also focuses on art movements that students learn from Art Nouveau to Impressionism and Symbolism to Contemporary art. Unfortunately, it is often ignored that there are some serious connections between art and design practices. And students graduate from design departments with the luck of such findings.

This research will examine and analyze the visual similarities between art and design. During this research, such questions were asked to find out; what are the basic approaches when an artist and a designer create their works? Are there any specific principles that they separate art and design from each other? Or are there any principles that bring them together?

The research will seek answers from such questions through specific artist and designer. The comparisons the works of Salvador Dali, as an artist, and Francis Storowski, as an illustrator and designer, will give us some ideas regarding the position an image in art and design. Findings from this research will help students as well as designers in general, to create works that communicate without getting into unclear and vogue situations.

Therefore, it would be necessary to mention the regarding philosophy of Dali' works in next pages. Storowski works will be analyzed on following that. And finally, analytic comparisons works of Dali and Storowski will help us to understand the role of an image in art and design.

\section{Findings and Comments}

\section{Salvador Dali}

Sidra Stich mentions Dali's works as "devestation and displacement", while he describes the deformations in these works as "a decaying or embryonic body, melting watches...vultrous insects, or isolated individual." (Stich, 1990: 90). Especially in some of his works Dali, just like Storowski, used symbolic images representing death. Some of these works are: "The Visage of War, 1940", "Atmospheric Skull Sodomizing a Grand Piano, 1934", "Daddy longlegs of Evening...Hope, 1940", "The Temptation of Saint Anthony, 1946" and "Average Atmospherocephalic Bureaucrat in the Act of milking a cranial Harp, 1933." Stich says that the reason of death, fear, and pessimistic feelings in Dali's works is the First World War and the Spanish civil war (Stich, 1990: 91). Dali's "The Face of War, 1940-41" is a works that shows death's close relation to fear. 


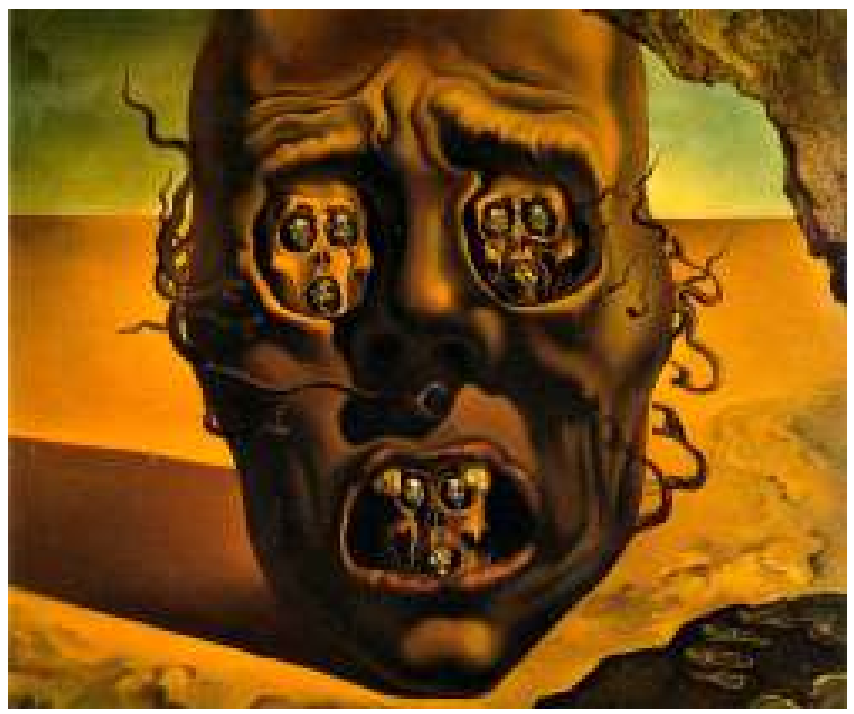

Resim 1. Dali, Salvador. "Face of War", 1940-41, Oil on panel, $100 \mathrm{~cm}$ x 79 cm, Museum Boijmans Van Beuningen, Rotterdam.

In this work having dominant colours of yellow and orange, a decaying human face is equated to a skull, and the same image is repeated twice in eyes and month. This death that represents the war's face, become more scary and propulsive with the little snakes on the right and left parts of the skull. Robert Descharnes, an art historian on Dali, defined the work in question as "the horrible face of war, its eyes filled with infinite death" and implied that this work is a reflection of Dali's fears during the Second World War and the Spanish civil war (Descharnes, 1985: 96). The same work is defined by another art historian Gilles Neret as follows: "Dali is deplaying optical tricks, employing double and triple images, sometimes multiplying them to infinity." (Neret, 2002: 47). Some of Dali's figurative and object works are heavly deformed. We can name such works as fallows: "Invisible Sleeping Woman, Horse, Lion, 1930". "The Endless Enigma, 1938." "Portrait of Picasso, 1947" and "The Temptation of Saint Anthony, 1946." We may well think that fear, individual loneliness, absence, absurdity and pessimism reflected by Dali's, The Face of War and many of his other works is a reflection of war and violence of his time. Indeed, the artist explains the scary effect the Spanish war had on him with the words; "The foreboding of civil war haunted me" (Neret, 2002: 45), and confessed that these feelings reflected to his latter artistic life: "A period of asctic rigor and of a quintessential violence of style was going to dominate my thinking and my tormented life." (Neret, 2002: 50).

Neret, explains another important subject dominant in Dali's works as follows: "The two motors which drive the supersine artistic mind of Salvadir Dali are first, the libido or sexual instict, and second, the fear of death." (Neret, 2002: 47). Dali explains his feelings on sex and death as follows, "for me eroticim must always be ugly, the aestetic always divine, and death beautiful." (Neret, 2002: 17). Dali has also applied deformations on women figures to a different extent. In this respect, in some of his works, certain women figures are transformed into men figures or other forms, in others these figures are presented in meaningful relationships with objects in a symbolical way. For instance, artist's work named, "The anthromorphic Cabinet, 1936 " is based on the relationship of a humane figure with the drawers of a cabinet. 


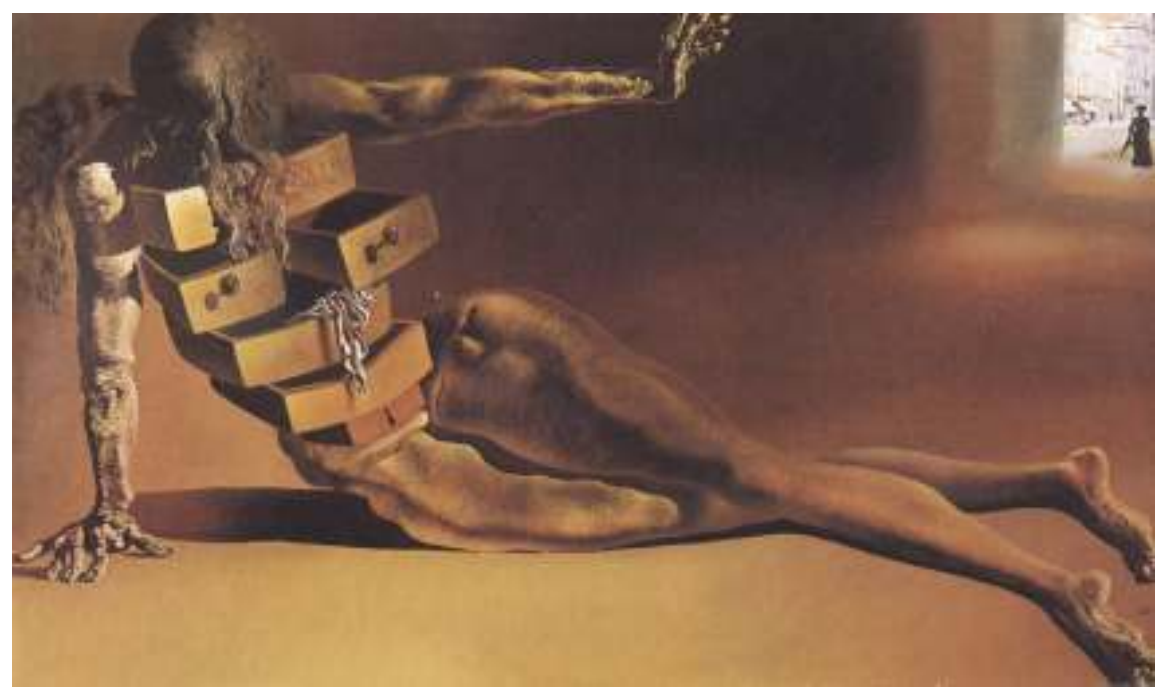

Resim 2. Dali, Salvador. "The anthromorphic Cabinet, 1936”, Oil on panel, $25 \mathrm{~cm} \mathrm{x} 43 \mathrm{~cm}$, Kunstsammlung Nordrhein-Westfalen, Düsseldorf, Germany.

In this work, Dali has multiplied the drawers of a cabinet from the breast of a woman to her abdominal region in various partitions and sizes. The women figure is illustrated sitting laterally on her right hand while her hair covers her face because of her inclination. The left hand of the figure is turned towards the light from the upper right corner of the picture and points at the human crowd there. It is possible to list similar styles of work of the artist such as, "The Burning Giraffe, 1936-37", "Venus de Milo with Drawers, 1936", and "Women with Drawers, 1936". The common feature of Dali's pieces of art above is the ambiguous and interesting affinity of the figure and the objects like the drawers of a cabinet. Due to the "collage" method of the artist, it is possible that the human figures and the non-human symbolic objects institute different meanings. For instance how is it possible to figure out a meaningful outcome from the work of the artist such as The Antromophic Cabinet?

The symbolic drawers of Dali's cabinet are associated with Freud as follows, "...the drawers suggest the obscure recesss of the human mind, in the sense of Freud's conception of the unconscious" (Ades and Taylor, 2004: 258). Neret also gives support to the above assertions and claims that Dali "borrowed" these symbolic objects from Freud and quotes the comments of Dali on this matter, "...drawers which only psychoanalysis is capable of opening" (Neret, 2002: 44). Neret, also explains some of the drawers observed in Dali's works could be associated with war and says, "But drawers could also realease a different, nauseating type of smell from a strange kitchen-war." (Neret, 2002: 44). It would be appropriate to relate the woman figure and the drawers of the cabinet in Dali's The Antromophic Cabinet work with war and violence. It would be meaningful for the woman figure in this work to blend together with the drawers of the cabinet right in the middle of the streets and to direct her hand towards the people as if begging for help. The women figure with drawers of the cabinet could give the message that she has nothing to give in total destitute.

In majority of his artwork, Dali has usually associated women figures with different objects or animals with the purpose of establishing conceptual images that would raise symbolic meanings. "Rainy Taxi, 1938" is another works of Dali which a woman model is placed in a taxi. 


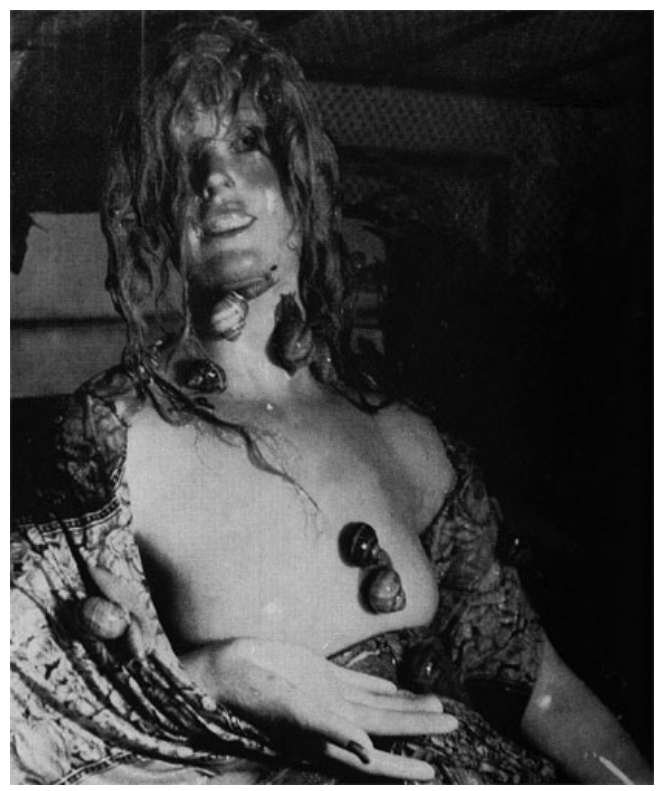

Resim 3. Dali, Salvador. "Rainy Taxi, 1938”, (Mannequin Rotting in a Taxi-Cab) (1938). At the international Suurealist Exhibition at the Galerie des Beaux-Arts, Paris

In this three dimensional work which was exhibited at the first international Surrealist Exposition, Galerie des Beaux-Arts, in Paris in 1938, snails are located on the breast and face of the woman figure. Dali made the surface of this model wet, thus enabling the snails to journey on the woman's body. In this work, a "strange" relationship is established between the woman and the snail that could be interpreted in various ways. While some people can look at this work through sense of humor perspective, some women would consider this to be an unacceptable and insulting behaviour.

The strange and problematic images especially seen in some of Dali's artworks. Supversive connections of women and objects are also observed in the work of other surrealist artists such as Max Ernst and Magritte. Rudolf E. Kvenzli explains the illustration of women just like an object in different forms and images as "male fantasies" (Kvenzli, 1991: 18), while Marry Ann Caws mentions the place of the woman concept in Surrealism by saying, "Surrealist woman, problematic and imprisoned, for the other eyes." (Caws, 1991: 11). Gwen Rauberg claims that the position of the women in Surrealist movement is "dominant" but also "muted" (Rauberg, 1991: 2) and David Hopkins holds up the same idea for women and says, "They [Woman] complicated, rather than foreclosed, questions of sexual identy." We know that people and especially women in Dali's and works of other surrealists as well as object figures are presented in a certain "systematized confusion" (Moorhouse, 2001: 25). The reason of the unethical and destructive approaches in the artwork of Dali and other artists are due to the fact that war and violence are at extreme points during that period. Therefore we may assume that in the endeavour of reflecting their own psychology, these artists have exploited "irrational", "subvertive" "humorous" and "absurd" images.

The attitudes similar to shocking and unexpected association of women and objects in Dali's and particularly other artists' works are also seen in other works of different artists after 1950's. Neret summarizes this state of affairs by saying, "Dali opened the way for many artists, from Bellmer to Allen Jones, allowing them to play with dolls and transform women into chairs 
or tables." (Neret, 2002: 44). The "absurd" and "irrational" relationships among figures of people, animals and objects are also seen in some of the works of the modern Polish poster designer Franciszek Starowieyski. Before getting into comparesion the works of Starowieyski and Dali, it is important to mention about Starowieyski and his works in following pages.

\section{Francis Storowski}

Storowski, who was born in 1930, in Krakow had his educated in "painting and graphic design" department of the academy (Alan and Isabella Livingston, 2003: 203). After completing his education Storowski had become a prominent figure especially with his theatre and film posters both in his country and abroad. Alexandre describes Storowski's importance in the world graphic art and especially in his country as the "uncrowned king" (Alexandre, 1976: 23). It is the fact that the importance of Storowski's posters emerges from the absurdness, irrationality, and bizarre in his illustrations where his works can be link with the works of Dali and surrealism in gereral. Steven Heller says the language used in Storowski's posters is "surrealistic vocabulary", (Heller, 1983: 203), while Alan Weill describes the details the artist uses as follows: "In his output, surrealism fallowed upon fantasy, the barogue upon the bizarre, dreams justled with nighmares and chimeras with fantastic animals." (Weill, 1985: 324). Francis Storowski and other prominent names of his generation, namely, Jan Lenica, and Roman Cieslewicz employed "irrationality" "dream" and "absurdness", the traits of surrealist art in their poster illustrations. Alan Weill and Szymon Bojko, the art historians known for their works on Polish poster art, define this important three poster artist's period that also include Storowski as "Polish Poster School. Mariusz Knorowski describes "Polish Poster School" period after 1950's as follows: "There was now a provoking game with the wiever's imagination, a grotesque, a psycjological study of the characters accompanying the naïve perceptions characteristic of child's sensitivity." (Knorowski, 1996: 39). To the definitions above which I assume to exist also in Storowski's works, Zdzislaw Schubert makes the following additions: "They suggested it trough allusions, sometimes by remote associations, often using irony, paradox and even graphic provocation." (Schubert, 1995: 20). Alexandre also explains the close relation of these important members of Polish Poster School art with Surrealism saying; "(they) were baptized with the waters of surrealism." (Alexandre, 1975: 40).

Approaches such as "subjective vision, irrationalism, freedom of association and creative intuition" (Aulich and Stlvestrova, 1999: 39), that reflect to Storoswki and other "Polish Poster School" members' posters are linked to the era's social and political events. Alexandre explains the negative conditions that persisted during the era of these poster artists as follows:

They became witness of the war, the humiliation and the terror of Hitler's regime at a young age in which experiences and sensations make an indelible impression, and that after the yearned-for "liberation" all hopes for a better and more reasonanle world vanished in the face of an age dominated by death and devil, by suicidal materialistic hybris, by moral degeneration and contempt of human dignity, an age which might easily have an apolyptic end (Alexandre, 1975: 40).

The symbolic images and objects in the works of this generation including Storowski became visible through exaggerated body deformations. Meanwhile, dreamlike images with nonsense appearances have become dominant. The human figures in Storowski's poster illusions, and especially images of women, give the impression that they are subjected to fear and violence.

Starowieyski's illustrations in his posters incorporate elements of death, violence, sexuality and fear just like the artwork of Dali. It is possible to make a list of similar works of the 
artist such as, "Posthumous Customs Gone Amok, 1983", "Sick Man's Prayer for the Night, 1989", "Teresa Desqueyroux, 1964", "Sanatorium Pod Klepsydra, 1973” and " Penderecki, Polish Requiem Homage Victims of Katyn Genocide". The association of sex, violence, death and fear in Dali's works like The Face of War and The Antropomorphic cabinet that we have examined above could be compared with the theatre poster of Starowieyski in "Don Giovanni, 1997 " and analogous parallel associations could be revealed in this one, too.

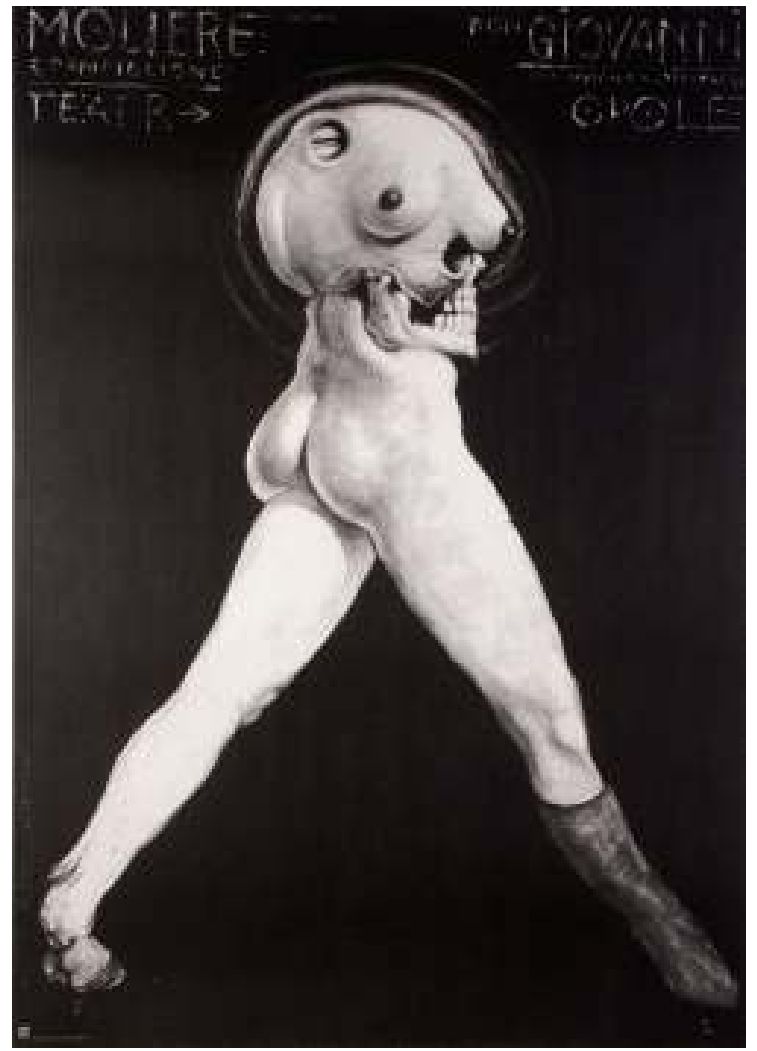

Resim 4. Starowieyski, Franciszek. "Don Giovanni, 1997”. 50 cm x 70 cm, Poland

\section{Comparasions}

In this work, Starowieyski has pictured the lower part of a woman's body while walking and combined the upper part of her body with the skull and the breasts to create a strange and extraordinary figure. In this image also the eyes of the skull are also located in the place of the breasts. Besides, the left foot of the strange and this bizarre image has an animal like quality. This strong illustrative and symbolic work may associate different meanings. It is possible to elucidate the topic in a way that could put a light on the meaning of this work as follows:

The story is set in Spain, and is based on the Don Juan legend. Don Giovanni is a ladies man, but in an accident he kills the important father of one of his mistresses. He runs away, but the father returns as a terrifying statue and takes Don Giovanni to hell. (Favorite Classical Composer, 2015)

Starowieyski has illustrated the life of Don Juan (on whom Giovanni is based) who was a character in the theatretical play interwoven with sex, violence and death in an "absurd" and "irrational" style. Even though the poster illustration of Starowieyski is evaluated in terms of general symbolic meanings, it makes a particular contribution to the meaning of the above 
theatretical play. We may imagine the reason of death of Don Juan to be based on women, sex, violenece, death and animal insticsts. Starowieyski has dramatized these indications with his own visual interpretation to attach an interesting and shocking quality to the theatre poster. Raymond Vezina claims that the illustrations in most of Starowieyski's posters give impressions of "shocks, evokes laughter, sympathy, disquest and testelessness" and explains the most significant aspect of Starowieyski's works with his words, "he [Starowieyski] created a rich world of wonderful ugliness and frightening beauty, where eroticism thrives in the permutations of different worlds." (Vezina, 2000: 55). Starowieyski has presented the opposite and repulsive association of the skul that represents death and woman, which represents life in a mastering talent. The artist has united both elements in a world of fantasy and surrealist atmosphere in order to bring about a powerful poster. In this reconstructed image beauty, ugliness, violence, love and sex may live together and may exhibit a "visual shock" (Torri, 1992: 28) in this way. Dali's works we have analyzed above like The Face of War and The Antropomorphic cabinet may be considered to be in parallel with Starowieyski's poster of Don Gionanni. Dali had illustrated the power of death and violence by recapping the skull in The Face of War. Again, in his work named The Antropomorphic cabinet Dali formed symbolic meanings by fusing the woman with the drawers of a cabinet. The strange appearance of the womand and the drawers in Dali's piece of art as well as the conceptual meanings arising from this image have turned out to be more specific and clear in Starowieyski's Don Gionanni. Even though Starowieyski has illustrated the relationship of death and sex in an "irrational" and "absurd" image through systematic deformation, this work could also indicate various interpretations that could make it "rational" at the same time.

Other than most of his work including deformations, some of Dali's artworks are presented in simple combinations that divulge shocking and suprising images. The artist's work named Rainy Taxi was shown as an example of this. In this work, Dali had placed the snails on the breasts and other body parts of a three dimensional model in order to establish "absurd" meanings in between the woman and the insect. In fact Dali has created an unexpected "magic" in this artistic act (Wescher, 1968: 198-199).

Dali's artwork Rainy Taxi which we assume to be absurd and ambiguous has parallel connotations with Starowieyski'nin "Hedda Gabler, 1997" 


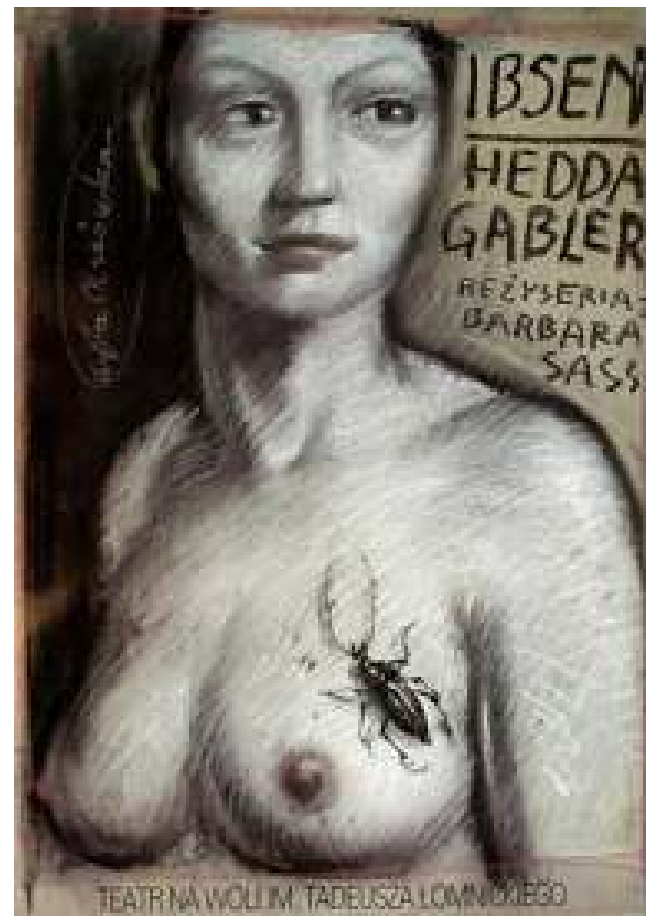

Resim 5. Starowieyski, Franciszek. "Hedda Gabler, 1997”. 50 cm x 70 cm, Poland

In this work, Starowieyski has illustrated an insect over the breasts of a young woman. In this piece of art where pattern design is outstanding, the scripts about the theatre are placed on the upper left and lower parts of the poster. The face of the woman in the poster is designed in a dull manner without any element of excitement. The detail that makes the poster interesting and appealing is the positioning of the insect on the breasts of the woman. The spectator will either combine this strange relationship in the poster with a conceptual image or attain definitive information on the theatretical play. In this respect the relationship between the woman in the portrait and the insect is highly ambiguous and could be directed towards many specific meanings. In order for us to get some more hints on the association of the woman-insect, it is possible to summarize the play as follows:

When a selfish, cynical women with a fascination for pistols tires of her marriage to a scholar, she wreaks havoc in the liveuitos of others by attracting the attention of a ne'er-do'well judge and forcing the suicide of a former sr who had taken up with her friend. When the judge tries to blackmail her into a relationship, she commits suicide instead (Archive, 2015)

It is possible to assume that the dull looking woman figure in Starowieyski's poster is Hedda Gabler. In this case, why has Starowieyski drawn an insect on the chest of the play's character? Has he employed this method because he thinks that Hedda Gabler in this play is as worthless and desperate as an insect? This could be interpreted in a different ways by saying that Gabler's inhumane behaviour in the play is much close to the point of animalization. Even though our assessments include close association between the play's main character and the insect, these will not acquire any certainty since we already know the personal interpretation of Starowieyski. In spite of this, we may still consider that Starowieyski froms an ironical and parallel relationship between the woman and the insect. This connection will at least give us a 
hint for relating the poster and the theatretical play. The woman-insect association in Starowieyski's poster and the relationship of the model and the snail in Dali's work are parallel in terms of the correlation, appearance, implementation and tactic. Both of the artists have intervened in the woman figures with an external insect. This relationship is realized without any physical deformation in the women's figures in a method of montage and "juxtaposition". In both of these works, the woman figure has attached attractive and appealing quality to the posters.

Starowski's another poster, "Baron Munchausen, 1972", will be discussed and analyzed in this section. It is considered to have some connections with the works of Dali.

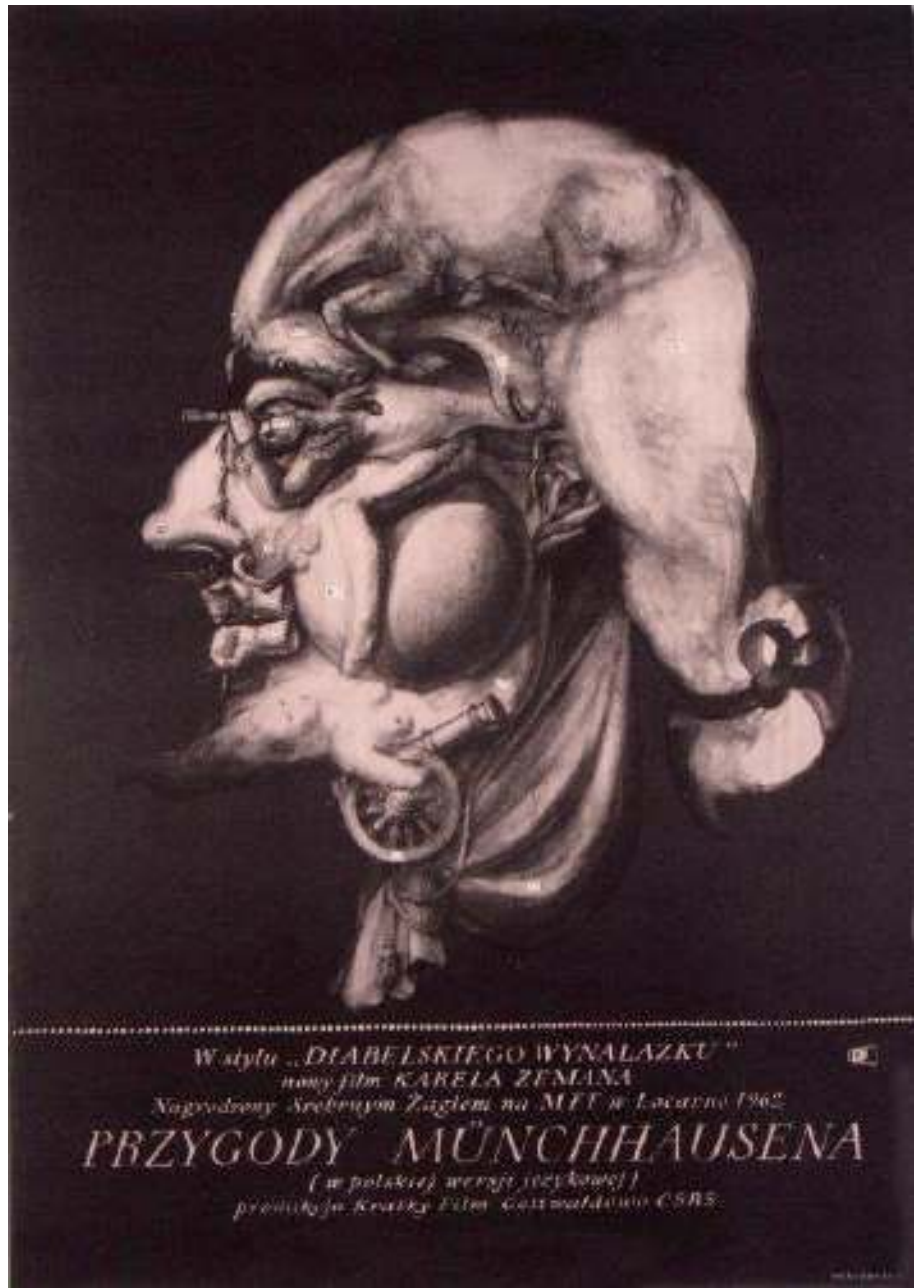

Resim 6. Starowieyski, Franciszek. "Baron Munchausen, 1972”. $50 \mathrm{~cm}$ x 70 cm, Poland

Starowieyski illustrated a human portrait with various objects and animal figures. The head and forehead of this human figure drawn on the profile is formed by a horse figure, while the eye and the cheeks are formed of a human figure that is looking forward. The mouthpart of this portrait is made of two cut hands (one of the hands holds a gun, and the other holds a sword). The round beard of this figure forms the hair of a woman while the chin is formed by the woman's body (this woman holds on one of her hands the cannon used in war). Besides, the collar of the shirt in this portrait is forming a curtain that could be used in a theatre while the hair 
at the back of this figure forms a huge money purse. Starowieyski has created a "magical" image by combining such various and different objects and figures. In order to better apprehend this complex poster image, it is possible to summarize the topic of this movie play as follows:

The fantastic tale of a 17th century aristocrat, his talented henchmen and a little girl in their efforts to save a town from defeat by the Turks. Being swallowed by a giant sea-monster, a trip to the moon, a dance with Venus and an escape from the Grim Reaper are only some of the improbable adventures (IMDb, 2015).

In respect to the above-mentioned summary of the movie, we may assume that the portrait's main character in Starowieyski's poster is Baron Munchausen. Starowieyski has illustrated the Baron Munchausen portrait in the poster image with some refences such as the horse, woman, war cannons, arms, and moon, which were presented in the movie. We may argue that Starowieyski's this creative and justaposed portrait is another version of the artworks of Surrealist Dali. The parallel relationship among the works of Dali and Starowieyski reflect a style where the fundamental figures in a portrait such as the face, eyes, ears, nose, mouth and hair are replaced with different objects and figures. Despite this association, the artists have illustrated these portraits with various intentions in terms of their positions. For instance, the symbolic elements like the woman; gun carriage, arms, curtain and the horse in Starowieyski's Baron Munchausen poster have been presented in the poster for bringing out a visual meaning. This situation is also valid for the drawers of the cabinet and the woman figure in Dali's The Antropomorphic cabinet artwork. The objects and figures used in the works of Starowieyski and Dali present symbolic meanings with their "irrational" and "dream-like" images. Jerzy Karo implies that by presenting symbolic images in a method of "fantasy or facts" (Karo, 1976: 60) establishes expressions in the posters while Dawn Ades entails that symbolic images are required for a "utopian society" (Ades, 1984: 10). Also, Paul Rond expresses that symbols are transformed into different meanings by the designers with the following words; "the designer is able to manipulate it, alter its meaning, and exploit its visual possibilities." (Rand, 1970: 19). This designation of Rand is in particular justifiable for Starowieyski's poster work, Hedda Gabler. The artist has symbolized the relationship of the insect and the woman in this work and thus asked the spectator to establish this association. Finally, Marta Stlvestrova and James Aulich mention that Starowieyski's posters are based on "metaphors and sembols" in their research on East European poster art (Aulich and Stlvestrova, 1999: 57).

The women and men figures in Starowieyski's works are described to be "tormented and eviscenated bodies...recurrent visions of ruin, deat and deliquescence". Starowieyski makes the following defense against tendencies of "horror, cruelty, some demonic expressions, magic, kabbalah and masochism" (Starowieyski, 1999: 48) that are claimed to be present in his art and says, "My figures have wonderful dreams, noble gestures. I dream of a perfect and ideal art." (Alexandre, 1980: 26; Graphis, 1971/1972: 498). Alain Weill, describes Starowieyski as "the fantasy surrealist" due to the unexpected and surprising deformations in the poster images of the artist (Weill, 2004: 106) while Zdzislaw Schubert argues that there are "surrealist connotations" in Starowieyski's images (Schubert, 1996: 42). As a matter of fact, we may consider the elements of "connotations" in Starowieyski's work with the "weird compositions of human body parts and animal skull, completed with wing like structures," in Dali's work. There is no doubt that the poster illustrations in Starowieyski are not the figures and objects we are used to in daily life. The artist presents "magic" images to the spectator just like in Hedda Gabler and Baron Munchausen by presenting the characters in the film or theatre with extraordinary qualities and additional imaginative elements. Actually, Starowieyski presents these imaginative figures in a certain 
"rational intepration" (Knorowski, 1996: 53) by enabling us to establish a certain association between the poster image and the film or theatretical play. Another parallel relation between the artwork of Starowieyski and Dali is the absurd figures of the images, which have imaginative and extraordinary appearances. Marianne Ouesterreicher-Mollow mentions that Freud has contributed to the placement of the language of dreams at the centre of the artwork of Dali and other surrealists (Ouesterreicher-Mollow, 1979: 14). The interest of Dali and other surrealists with dream and the subconscious is in relation with this fundamental assumption of Freud; "The interpretation of dreams is the royal road to a knowledge of the uncouncious activities of the mind." (Freud, 1967: 608). As I had already stated that Freud had stated that the surrealist work of Dali and other surrealists are distant from his scientific enterprise. Finally Freud had expressed the following on this matter, "in classic paintings, I look for the sub-concious-in surrealist paintings, for the conscious." (Maddox, 1979: 72). Despite Freud's negative approach towards the Surrealists, the interest of the artists in this movement on especially dreams and the subconscious has created an effect of "the creative power of imagination" in this movement (Fontana, 1994: 13). We may particularly see this effect as an outcome in dream's "absurd encounters and transformations" and "its paradoxical combinations" (Schmeller, 1980: 9).

Moreover, Moddox considers his approach towards Dali's works in a way of "translating hallucinations and dreams into a concrete reality" (Maddox, 1979: 39), and John Barnicoat implies Dali's attitude that could be described as "to allow the uncounscious mind to produce images illogically" as a conscious activity (Barnicoat, 1985: 161). In this respect, we may advocate that the images that Dali has formed with a "paranoiac-critical" method and which reflect the subconscious are in fact "illogical" images. It is possible to see "the shock, mystery and surprise" (Salvador Dali A Panaroma of His Art, 1974: 145) effects that the images and objects generate in Dali's works in the posters such as Starowieyski's Don Gionanni, which we have analyzed it earlier. On the other hand, it is also possible to come across the expressions of ideas in Starowieyski's poster images in Dali's "paranoiac-critical" type of work. The significance of the ideas and expressions that are presented in Dali's works could be described as follows: "The idea has always been the most significant thing than not the technique." (Salvador Dali A Panaroma of His Art, 1974: 163). The concepts and ideas in the posters of Starowieyski are naturally required for establishing communication. In this case, the obscure "idea" observed in Dali's works are presented in "irrational" and "absurd" expressions consciously.

Dali's implication on today's modern poster and commercial arts has not only instituted merely an indirect but sometimes direct interaction. David Sylvester claims that the "fantasy" images that Dali has attained in his work are influential in today's "commercial art" (Sylvester, 1992: 20). For instance the artist has designed the book cover of Carles Fages de Climent's book named 'Les Bruixes de LIers' during the commencement of his artistry and also prepared commercial illustrations for Spanish magazines such as "Espana" and "Alter" (Dali, 2004: 471). Against the criticizations that Dali's artwork was used in business world, he responds with the following explanation and says, "it is not true...commerce has come to Dali, the dealers have been Dalified" (de la Serna, 1978: 34). The founder of Surrealist movement, Breton makes the subsequent assessment on Dali's work related with the business life; “...from 1936 onwords has had no interest whatsoever for surrealism." (Breton, 1965: 76).

The most important reason why Dali's artwork is used in illustrations in various posters, commercials and magazines in the business world is due to the "various inteprations" of the images in such work. The imaginative images of the artist were used in Shirley Temple's election 
campaign in California (Novum, 1973: 6). His other works like "Café de Chiritas, 1943, "Mad Tristan, 1944", and "Sentimental Colloguy, 1944" ornamented the walls of a theatretical play (Amberg, 1947: 289). In addition to these, for the advertising agency named Cecil \& Presbey, Dali prepared several commercial illustrations for the famous Bryan Nylon Hosiery brand (Graphis, 1947: 88). In the commercial illustrative artwork named Chen $Y u$ for promoting lipsick and nail polish, Dali has illustrated the hand of a woman right in the middle of scenery.

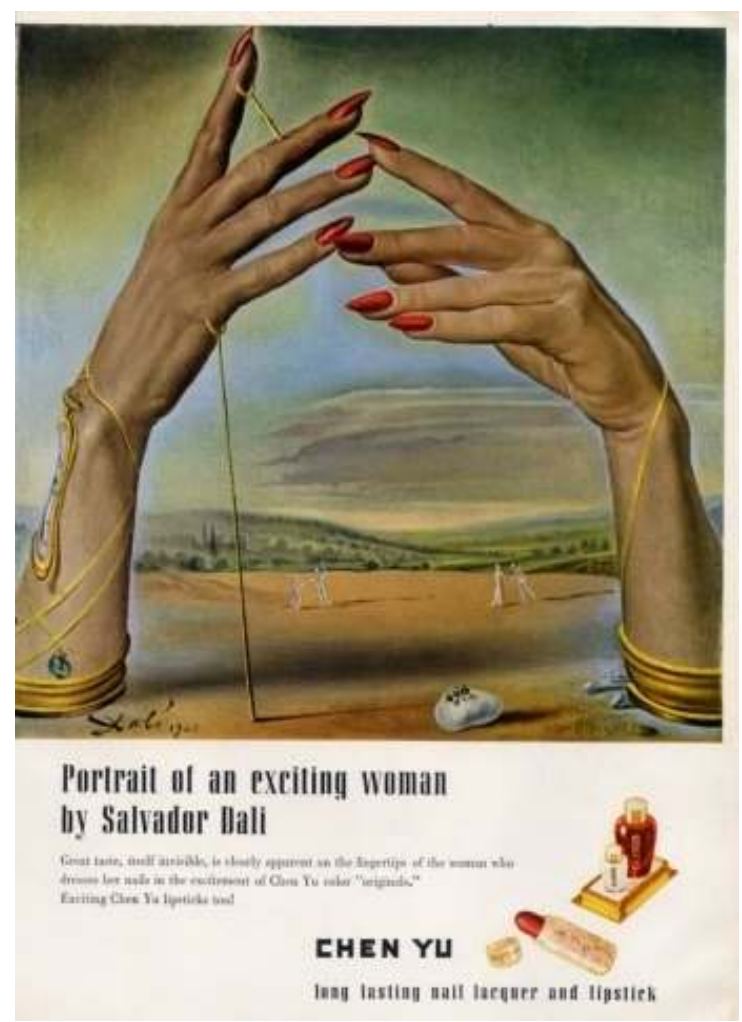

Resim 7. Dali, Salvador. "Chen Yu, make up ad, 1940s”, New York.

The red polish on the woman's nails in the image is associated with the color of the product located at the bottom of the commercial. Dali has placed the normal sized scenery and the people at the lower part of the illustration, which is in conflict with the greater sized hand of the woman in this "irrational" world.

\section{Conclusion}

It can be concluded that Dali used his surrealist artworks both for the sake of art and also for images in advertisings, magazine illustrations and posters. At the same time contemporaray poster designers like Starowieyski also used surrealist illustrations in his poster in order to shock and get attention of the public. To sum up, Dali's "irrational", "obcure", "absurd" and "dream" type of surrealist works are in parallel with Starowieyski illustrations, which were made for the porpuse of communication. 


\section{References}

Ades, D. (1984). Posters: The $20^{\text {th }}$ Century Poster Design of the Avant-Garde. New York: Abbeville Press.

Ades, D. and Taylor, M. R. (2004). Dali. NY: Rizzoli.

Alexandre, A. (1975). Novum, Vol 1, 46. No. 5. Germany.

Alexandre, A. (January 1976). Franciz Storowski. Novum Magazine. Germany.

Alexendre, A. (1980). Novum. Vol. 51, No: 1.

Amberg, G. (1947). "Ballet Design in the United States" in Graphis. Volume 3, No: 20.

Aulich, J. and Stlvestrova, M. (1999). Political Posters in Central and Eastern Europe 1945-95. Manchester and New York: Manchester University Press.

Barnicoat, J. (1985). Posters: A Concise History. New York: Thames \& Hudson.

Breton, A. (1965). Surrealism and Painting. London: Macdonald Pub.

Caws, M. A. (1991). "Seeing the Surrealist Woman: We Are Problem" in Surrealism and Woman by Marry Ann Caws. Rudolf Kvenzli and Gwen Rauberg, Cambridge, Massachusetts and London: MIT Press.

Dali. (2004). New York: Rizzoli and Philodelphia Museum of Art.

de la Serna, R. G. (1978). Dali. Milano: Arnoldo Mondadori Editore.

Descharnes, R. (1985). Dali. New York: Harry N. Abrams, Inc., Publishers.

Fontana, D. (1994). The Secret Language of Dreams. San Francisco: Chronicle Books.

Freud, S. (1967). The Interpretation of Dreams. London: George Allen \& Unwin.

Franciszek Starowieyski. (1999). Krakow: Kwadrat Pub.

Graphis. (1947). Vol:3, No: 18.

Graphis. (1971/1972). No. 157.

Heller, S. and Chwast, S. (1983). Graphic Style: From Victorian to Digital. New York: Abrams.

IMDb. (November $5^{\text {th }}$ 2015). Retrieved from http://www.imdb.com/title/tt0096764/plotsummary

Karo, J. (1976). Graphic Design: Problems, Methods, Solutions. NY: Van Nostrand Reinhold Campany Inc.

Knorowski, M. (1996). "The Poster" in Museum of the Street. Warsaw: Museum Publication.

Kvenzli, R. E. (1991). "Surrealism and Misogyny" in Surrealism and Woman by Marry Ann Caws, Rudolf Kvenzli and Gwen Rauberg, Cambridge, Massachusetts and London: MIT Press.

Archive.org. (November $5^{\text {th }}$ 2015). Retrieved from https://archive.org/stream/HenrikIbsenTheFatherOfModernDrama/HenrikIbsen_djvu.txt

Livingston, A. and I. (2003). Graphic Design and Designers. London: Thames and Hudson.

Maddox, C. (1979). Dali. NY: Crown Publishing. 
Moorhouse, P. (2001). Dali. London: PRC Publishing Ltd.

Neret, G. (2002). Dali. Koln: Taschen.

Novum. (1973). No: 4, Berlin.

Favorite Classical Composer. (November $\left.5^{\text {th }} 2015\right)$. Retrieved from

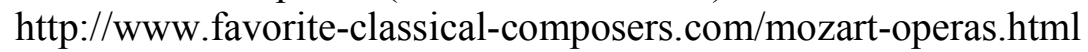

Ouesterreicher-Mollow, M. (1979). Surrealism and Dadaism. Oxford: Phaidon Press Limited.

Rand, P. (1970). Thoughts on Design. London, New York: Studio Vista and Van Nostrand Reinhold.

Rauberg, G. (1991). "The Problematic of Woman and Surrealism" in Surrealism and Woman by Marry Ann Caws. Rudolf Kvenzli and Gwen Rauberg, Cambridge, Massachusetts and London: MIT Press.

Salvador Dali A Panorama of His Art. (1974). Ohio: The Salvador Dali Museum.

Schmeller, A. (1980). Surrealism. New York: Crown Publishers, Inc.

Schubert, Z. (1995). Master of Polish Art. Warsaw: Buffi Publication.

Schubert, Z. (1996). "The Glorious Years 1947-67" in Polish Film posters: 1896-1996 by Krzysztof Dydo. Cracow: Galaria Plakatu.

Stich, S. (1990). Anxious Visions: Surrealist Art. NY: Abbeville Press.

Sylvester, D. (1992). Magritte. The Silence of The World. NY: The Menil Foundation. Hanry N. Abrams, Inc.

Torri, G. (1992). Linegrafica. 278. Millano Azzuri Pub.

Vezina, R. (2000). "The Teratological Aspect of Polish Posters" in Polish Poster Theatre 1899. 1990 by Krzysztof Dydo. Cracow.

Weill, A. (1985). The Poster. London: Sotheby's Publication.

Weill, A. (2004). Graphic Design. A History. NY: Harry N. Abrams, Inc., Publishes.

Wescher. H. (1968). Collage. NY: Harry N. Abrams. 